\title{
Proteolytic activity in the adult and larval stages of the human roundworm parasite Angiostrongylus costaricensis
}

\author{
Karina Mastropasqua Rebello ${ }^{1,2,3}$, Caroline Reis de Siqueira ${ }^{1,3}$, \\ Erika Louise Ribeiro, ${ }^{1,3}$, Richard Hemmi Valente ${ }^{1,3}$, Ester Maria Mota ${ }^{2}$, \\ Jonas Perales ${ }^{1,3}$, Ana Gisele da Costa Neves-Ferreira ${ }^{1,3 /+}$, Henrique Leonel Lenzi ${ }^{2+}$ \\ 'Laboratório de Toxinologia, ${ }^{2}$ Laboratório de Patologia, \\ Instituto Oswaldo Cruz-Fiocruz, Rio de Janeiro, RJ, Brasil ${ }^{2}$ Rede Proteômica do Rio de Janeiro, \\ Fundação de Amparo à Pesquisa do Estado do Rio de Janeiro, Rio de Janeiro, RJ, Brasil
}

\begin{abstract}
Angiostrongylus costaricensis is a nematode that causes abdominal angiostrongyliasis, a widespread human parasitism in Latin America. This study aimed to characterize the protease profiles of different developmental stages of this helminth. First-stage larvae (L1) were obtained from the faeces of infected Sigmodon hispidus rodents and third-stage larvae (L3) were collected from mollusks Biomphalaria glabrata previously infected with L1. Adult worms were recovered from rodent mesenteric arteries. Protein extraction was performed after repeated freeze-thaw cycles followed by maceration of the nematodes in $40 \mathrm{mM}$ Tris base. Proteolysis of gelatin was observed by zymography and found only in the larval stages. In L3, the gelatinolytic activity was effectively inhibited by orthophenanthroline, indicating the involvement of metalloproteases. The mechanistic class of the gelatinases from L1 could not be precisely determined using traditional class-specific inhibitors. Adult worm extracts were able to hydrolyze haemoglobin in solution, although no activity was observed by zymography. This haemoglobinolytic activity was ascribed to aspartic proteases following its effective inhibition by pepstatin, which also inhibited the haemoglobinolytic activity of L1 and L3 extracts. The characterization of protease expression throughout the A. costaricensis life cycle may reveal key factors influencing the process of parasitic infection and thus foster our understanding of the disease pathogenesis.
\end{abstract}

Key words: Angiostrongylus costaricensis - metalloproteases - aspartic proteases - haemoglobin - zymography

Angiostrongylus costaricensis (Morera \& Cespedes 1970 ) is a nematode that causes abdominal angiostrongyliasis (AA), a human helminthiasis characterized by abdominal eosinophilic ileocolitis. Adult worms live inside the mesenteric arteries of rodents (definitive hosts). Eggs laid by females hatch to release first-stage larvae (L1), which migrate into the intestinal lumen and are eliminated with the faeces. The L1 larvae infect mollusks (intermediate hosts) and further develop into infective third-stage larvae (L3), which subsequently develop into adult worms in the mammalian hosts. Humans are incidental hosts and may become infected through the ingestion of infected mollusks or unwashed vegetables (Morera 1973). This parasitic disease has been reported throughout Central and South America (Morera \& Cespedes 1971, Incani et al. 2007, Palominos et al. 2008). In endemic areas, such as the southern region of Brazil, epidemiological and clinical features are used as diagnostic indications of AA (Agostini et al. 1983, 1984, Ayala 1987, Graeff-Teixeira et al. 1991, 2005, Bender et al. 2003, Mesen-Ramirez et al. 2008, Ben

Financial support: FIOCRUZ (PAPES V, PDTIS), CNPq, FAPERJ, CAPES

KMR has CAPES fellowship.

+ In memoriam

+ Corresponding author: anag@ioc.fiocruz.br

Received 10 November 2011

Accepted 9 May 2012 et al. 2010, Abrahams-Sandi et al. 2011). However, AA is a disease with unspecified clinical manifestations. To date, the only way to achieve an accurate diagnosis is through surgical intervention to find intra-arterial worms or eggs trapped in small capillaries in histological sections. Moreover, an effective pharmacological treatment for AA does not currently exist (Morera \& Bontempo 1985, Terada et al. 1993, Tungtrongchitr et al. 1993). Previous studies using noninvasive tools to diagnose AA have shown that available serological tests are not effective due to both nonspecific cross-reactivity issues and the diversity of humoral responses (Graeff-Teixeira et al. 1997, Geiger et al. 2001). A published method based on a polymerase chain reaction may eventually improve our ability to diagnose the disease, although the results are still preliminary (da Silva et al. 2003). Moreover, many studies have assessed different types of therapies with limited success, such as treatment with anthelmintic drugs (Morera \& Bontempo 1985, Mentz \& Graeff-Teixeira 2003, Bohrer Mentz et al. 2007), anti-inflammatory drugs (Fante et al. 2008) and antithrombotic agents (Rodriguez et al. 2011). The present consensus is that anthelmintic drug administration is not recommended given that it usually induces the erratic migration of worms instead of killing them (Morera \& Bontempo 1985). Therefore, new targets for the diagnosis and treatment of this helminthic disease are urgently needed.

Proteases are interesting biomarkers for the detection of diseases and account for roughly $10 \%$ of all current pharmacological targets (Lim \& Craik 2009). They catalyze the cleavage of peptide bonds in proteins and, based on their mechanism of catalysis, are classified into 
six distinct classes: serine, cysteine, metallo, aspartic, glutamic and threonine proteases (Lopez-Otin \& Bond 2008, Rawlings et al. 2012). Proteolytic enzymes have been implicated in several aspects of helminth development (Tort et al. 1999), including moulting (Hong et al. 1993, Rhoads et al. 1998), hatching (Xu \& Dresden 1986) and excystment (Chung et al. 1995). Moreover, parasitederived proteases are key elements in the process of host colonization by the infective larval stages of several helminths. In addition to assisting in connective tissue invasion and feeding, these enzymes help parasitic organisms to evade the host immune response and prevent blood coagulation (McKerrow 1989, Dzik 2006). They are major virulence factors because they play a variety of roles establishing, maintaining and exacerbating the infection (McKerrow et al. 2006). Proteases of different mechanistic classes may be expressed in the parasite intestines or may constitute their excretory-secretory products. They are presently considered to be potential targets for the next generation of antiparasite interventions (Dalton 2003). The aim of this study was to evaluate the presence of proteases in crude extracts of $A$. costaricensis nematodes at different developmental stages. We hypothesize that, as is true for other helminth nematodes, proteolysis is most likely involved in the nutrition, development and pathogenicity of $A$. costaricensis.

\section{MATERIALS AND METHODS}

Chemicals - Protease inhibitors [pepstatin A, Ltrans-epoxysuccinyl-L-leucylamido-(4-guanidino)butane (E-64), orthophenanthroline, 4-(amidinophenyl) methanesulphonyl fluoride (APMSF), ethylenediaminetetraacetic acid (EDTA) and ethyleneglycol bis(2aminoethyl ether)-N,N,N',N' tetraacetic acid (EGTA)], dithiotreitol (DTT), human haemoglobin and Coomassie R-250 were purchased from Sigma-Aldrich (St Louis, USA). The Sample Grinding kit, 2-D Quant kit and protein low molecular weight standards for sodium dodecyl sulfate polyacrylamide gel electrophoresis (SDS-PAGE) were from GE Healthcare (Chalfont St Giles, UK). All other chemicals were of analytical reagent grade.

Ethics - All procedures with animals were approved by the Animal Ethical Committee at Oswaldo Cruz Foundation (license \# P0246/05) and conducted in accordance with the International Guiding Principles for Biomedical Research Involving Animals, as issued by the Council for the International Organizations of Medical Sciences.

Parasite life cycle - Adult and larval stages of $A$. costaricensis nematodes were obtained from the normal life cycle of the parasites, which were kept in the laboratory through their successive passages in mollusks Biomphalaria glabrata (intermediate hosts) and rodents Sigmodon hispidus (definitive hosts), as previously described (Mota \& Lenzi 2005).

L1 - Three-month-old rodents were used after 30 days of being orally infected with $\mathrm{L} 3$ of $A$. costaricensis per animal. Faeces collected from these animals were added to $50 \mathrm{~mL}$ of water. L1 was decanted from the faeces suspension using a modified Baermann apparatus. The modification consisted of a funnel directly connect- ed to a haemolysis tube through a latex hose (Barcante et al. 2003). After $12 \mathrm{~h}, 50 \mathrm{~mL}$ of the sediment containing L1 were recovered and centrifuged at 2,000 $\mathrm{g}$ for 10 $\mathrm{min}$ at room temperature (RT). The supernatant was discarded and the remaining pellet was resuspended in 10 $\mathrm{mL}$ of water. After gentle agitation, suspension aliquots $(100 \mu \mathrm{L})$ were transferred to Petri dishes for counting and evaluation of the morphology of the larvae using an inverted light microscope. A discontinuous Percoll gradient was then used to separate L1 from small debris and bacteria as previously described (Graeff-Teixeira et al. 1999). This method takes advantage of the change in density that occurs when A. costaricensis larvae are killed, allowing for the separation of dead L1 from live ones. Following the purification step, the Percoll was removed by five cycles of phosphate buffered saline (PBS) washing and centrifugation at $2,500 \mathrm{~g}$ for $10 \mathrm{~min}$ at $20^{\circ} \mathrm{C}$.

L3 - The infective L3 were obtained from mollusks previously infected with L1. Briefly, mollusks were crushed and the tissues were homogenized and digested in an acid-pepsin solution $(0.5 \%$ pepsin and $0.2 \% \mathrm{HCl})$ for $2 \mathrm{~h}$ at $37^{\circ} \mathrm{C}$ (Wallace 1969, Mota \& Lenzi 2005). Host cellular debris was removed from the digests by centrifugation at 2,000 $\mathrm{g}$ for $10 \mathrm{~min}$. The infective larvae were then isolated according to Baermann's modified technique and counted as previously described for L1.

Adult worms (male and female) - Adult worms were recovered by dissection of the mesenteric arteries of $S$. hispidus rats 40 days after the infection (Wallace 1969, Mota \& Lenzi 2005). They were extensively rinsed in PBS, segregated according to gender (Rebello et al. 2011), weighted and then stored at $-80^{\circ} \mathrm{C}$ until further use.

Protein extraction - Samples containing 80,000 L1 or $30,000 \mathrm{~L} 3$ were resuspended in $300 \mu \mathrm{L}$ of $40 \mathrm{mM}$ Tris base in $1.5 \mathrm{~mL}$ microcentrifuge tubes containing abrasive resin (Sample Grinding Kit). Protein extraction was performed by a combination of 10 freeze-thaw cycles in liquid nitrogen followed by grinding for $2 \mathrm{~min}$. Adult worms (13 males or 7 females) were separately ground for $5 \mathrm{~min}$ in $1.5 \mathrm{~mL}$ microcentrifuge tubes containing abrasive resin and $150 \mu \mathrm{L}$ of $40 \mathrm{mM}$ Tris base. The optimization of the protein extraction procedures was performed on female samples only and included sample grinding in two additional extraction solutions: $40 \mathrm{mM}$ Tris base with $1 \%$ Triton X-100 or $40 \mathrm{mM}$ Tris base with $1 \%$ SDS. Cell debris was removed by centrifugation at $16,000 \mathrm{~g}$ for $10 \mathrm{~min}$ and the protein content of the supernatants was measured using the 2-D Quant kit and bovine serum albumin as the standard.

Zymography - The proteolytic activity of crude extracts of larvae and adult worms was analyzed by zymography using $12 \% \mathrm{~T}$ SDS-PAGE $(\mathrm{T}=$ total concentration of acrylamide and bis-acrylamide) (Laemmli 1970), containing $0.1 \%$ copolymerized gelatin (Heussen \& Dowdle 1980). Protein extracts $(2 \mu \mathrm{g})$ were diluted $(\mathrm{v} / \mathrm{v})$ in sample buffer without $\beta$-mercaptoethanol and loaded onto gels. The gels were run at $12 \mathrm{~mA}$ and $4^{\circ} \mathrm{C}$. After electrophoresis, the gels were incubated for $1 \mathrm{~h}$ at RT in $2.5 \%(\mathrm{v} / \mathrm{v})$ Triton X-100 for SDS removal and enzyme renaturation. 
The effect of $\mathrm{pH}$ on the proteolytic activity was determined by incubating Triton X-100-treated gels for $12 \mathrm{~h}$ at $37^{\circ} \mathrm{C}$ in the following buffers: $0.1 \mathrm{M}$ sodium citrate containing $1 \mathrm{mM} \mathrm{CaCl}_{2}$ (pH 3.0 or 5.5 ), $0.1 \mathrm{M}$ sodium phosphate containing $1 \mathrm{mM} \mathrm{CaCl}_{2}$ (pH 7.0), 0.1 M Tris containing $1 \mathrm{mM} \mathrm{CaCl}$ (pH 7.4), $0.1 \mathrm{M}$ glycine- $\mathrm{NaOH}$ containing $1 \mathrm{mM} \mathrm{CaCl}_{2}$ (pH 10) and $0.2 \mathrm{M} \mathrm{KCl}-\mathrm{NaOH}$ containing $1 \mathrm{mM} \mathrm{CaCl}$ ( $\mathrm{pH}$ 12). Zymograms were stained with $0.2 \%$ Coomassie Brilliant Blue (R-250) in methanol:acetic acid solution (40:10 v/v) and destained in the same solution without the dye. They were scanned with the ImageScanner III (GE HealthCare) and analyzed by the Image Master 2D Elite software (GE HealthCare).

Haemoglobin proteolysis in solution - Haemoglobin hydrolysis was assayed after the incubation of human haemoglobin $(0.5 \mathrm{~mL} ; 2 \mathrm{mg} / \mathrm{mL})$ with crude extracts of larvae or adult nematodes $(50 \mu \mathrm{g})$ at $37^{\circ} \mathrm{C}$ for $1 \mathrm{~h}, 5 \mathrm{~h}$ or $18 \mathrm{~h}$ in the presence of $1 \mathrm{mM}$ DTT. Digestions were conducted in the following buffers: $0.1 \mathrm{M}$ sodium acetate, $\mathrm{pH} 3.0$ or 5.0, and $0.1 \mathrm{M}$ sodium phosphate, $\mathrm{pH}$ 7.4. The reaction was stopped by the addition of sample buffer (Laemmli 1970) and boiling for $5 \mathrm{~min}$; the hydrolysates were further analyzed by $15 \% \mathrm{~T}$ SDS-PAGE under reducing conditions. Protein extracts $(50 \mu \mathrm{g})$ from the gut tissue of female worms were also tested upon the haemoglobin substrate as described above (18 h hydrolysis).

Inhibition of proteolytic activity - The following protease inhibitors were used to identify the mechanistic class of the proteases in protein extracts (molar concentrations used are indicated): $10 \mu \mathrm{M} \mathrm{E}-64,10 \mathrm{mM}$ and $100 \mathrm{mM}$ orthophenanthroline, $10 \mathrm{mM}$ EDTA; $10 \mathrm{mM}$ EGTA, $1 \mu \mathrm{M}$ pepstatin A and $100 \mu \mathrm{M}$ APMSF. They were included in the buffer in which the zymograms were incubated overnight following enzyme renaturation. To assay for the inhibition of haemoglobinolytic activity in solution, the inhibitors were added to the appropriate digestion buffer.

\section{RESULTS}

The optimization of protein extraction conditions was performed only in female adult worms, which are longer and more abundant than male worms (Rebello et al. 2011). Equivalent sample amounts ( $\sim 3.5 \mathrm{mg}$ of worm/ replicate for each condition) were ground in three different solutions followed by the estimation of protein recoveries by the 2-D Quant kit (Table). Quantitatively, when compared to the assumed $100 \%$ extraction efficiency (obtained with $40 \mathrm{mM}$ Tris base containing 1\% SDS), 40 $\mathrm{mM}$ Tris base containing $1 \%$ Triton X-100 or $40 \mathrm{mM}$ Tris base solutions allowed for the recovery of $81 \%$ and $45 \%$ of total worm proteins, respectively. Although detergents did not impair the proteolytic activity, the inhibitory efficiency of chelating agents was reduced in the presence of SDS. Therefore, to avoid interference in the inhibition assays, all protein extracts further used in this study were prepared in $40 \mathrm{mM}$ Tris base without any detergents, albeit with lower efficiency of protein recovery.

The zymographic analysis involves protein separation by SDS-PAGE copolymerized with a substrate within the polyacrylamide gel matrix. Following renaturation by the exchange of the SDS with a nonionic detergent, proteolytic activity was visualized in situ as clear bands against a dark blue background where the protease had digested the substrate (Wilkesman \& Kurz 2009). Calcium chloride was included in the hydrolysis buffer to improve the detection of calcium-dependent proteases (ex.: metalloproteases, serine proteases) which could eventually be present in the nematode extracts. This technique has proven extremely useful for the detection of a wide range of proteases from parasites, animals and plants (d'AvilaLevy et al. 2001, Santos et al. 2009). A drawback of the technique is that some enzymes do not renature correctly and hence cannot be detected (Wilkesman \& Kurz 2009).

A pronounced gelatinolytic activity was observed for the protein extracts of L1 and L3 larvae, the migratory stages of the parasite. For both larval stages, gelatinolytic activity was detected at a neutral and an alkaline $\mathrm{pH}$, with optimal activity observed at pH 7.4 (Fig. 1A). The SDS-PAGE analysis of the larval extracts (Fig. 2B) showed a complex pattern of protein bands, with molecular masses ranging from 97 to less than $14.4 \mathrm{kDa}$. On the other hand, most proteolytic bands showed apparent molecular masses greater than $40 \mathrm{kDa}$ (Fig. 2A). To determine the mechanistic class of the gelatinases of A. costaricensis, their susceptibility to the following protease inhibitors was analyzed: APMSF (irreversible inhibitor of serine proteases), E-64 (irreversible inhibitor of cysteine proteases), pepstatin (reversible inhibitor of aspartic proteases), orthophenanthroline, EDTA or EGTA (reversible inhibitors of metal-dependent proteases) (Fig. 3). The gelatinolytic activity of L3 extracts was insensitive to APMSF, E-64 and pepstatin, but was readily inhibited by orthophenanthroline, EDTA or EGTA, suggesting the major involvement of zinc metalloproteases. The proteolytic activity of L1 extracts upon gelatin was only partially inhibited by orthophenanthroline or EDTA. On the other hand, EGTA strongly inhibited the gelatinolytic activity of L1 extracts; this metal chelator has a very high affinity for calcium ions, suggesting the presence of calcium-dependent proteases in this sample. Given that APMSF, E-64 and pepstatin did not affect this enzymatic activity either, the mechanistic class of

TABLE

Quantitative analysis of different sample preparation methods for female adult worms

\begin{tabular}{llll}
\hline & \multicolumn{3}{c}{$\begin{array}{c}\text { Extraction yield } \\
(\mu \mathrm{g} \text { ptn/mg worm })^{a}\end{array}$} \\
\cline { 2 - 4 } Extraction solutions & Mean & $\mathrm{SD}$ & $\mathrm{n}$ \\
\hline $40 \mathrm{mM}$ Tris & 23.82 & 1.98 & 3 \\
$40 \mathrm{mM}$ Tris $+1 \%$ Triton X-100 & 43.25 & 5.12 & 3 \\
$40 \mathrm{mM}$ Tris $+1 \%$ SDS & 53.10 & 1.47 & 3 \\
\hline
\end{tabular}

$a$ : protein concentration was measured using the 2-D Quant kit assay; n: number of independent replicates; SD: standard deviation; SDS: sodium dodecyl sulphate. 
the gelatinases of L1 larvae could not be precisely determined. Worm extracts of male and female adults were unable to hydrolyze copolymerized gelatin over the wide range of $\mathrm{pH}$ values tested (not shown).

Host haemoglobin is a major substrate for the proteolytic enzymes produced by nematodes that feed on blood (Williamson et al. 2003). The present study showed that protein extracts from larvae (Fig. 4) or adult worms (Fig. 5) of A. costaricensis hydrolyze human haemoglobin in vitro after $18 \mathrm{~h}$ and $5 \mathrm{~h}$ of incubation, respectively. No hydrolysis of haemoglobin was observed after $1 \mathrm{~h}$ of incubation (not shown). Interestingly, haemoglobindegrading activity was also observed in protein extracts from isolated gut tissue of adult worms, with optimum activity observed at $\mathrm{pH} 3.0$ (Fig. 1B). The same $\mathrm{pH}$ behaviour was observed in crude extracts from adult worms
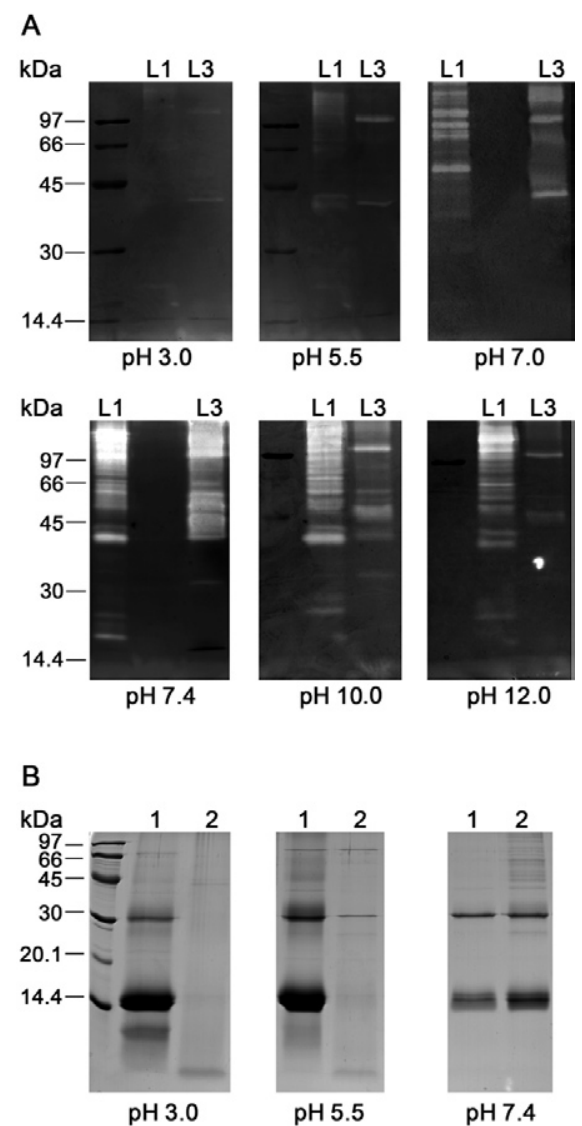

Fig. 1: A: gelatin zymograms showing the proteolytic activity of the protein extracts of first (L1) and third (L3) stage larvae of Angiostrongylus costaricensis nematodes. Samples $(2 \mu \mathrm{g})$ were loaded onto $12 \%$ sodium dodecyl sulfate polyacrylamide gel electrophoresis (SDS-PAGE) copolymerized with $0.1 \%$ gelatin. After the electrophoretic separation, the zymograms were incubated for $18 \mathrm{~h}$ at $37^{\circ} \mathrm{C}$ at different $\mathrm{pHs}$ (see Materials and Methods for the description of buffers composition). The zymograms were stained with Coomassie Brilliant Blue R250; B: SDS-PAGE (12\%) analysis of haemoglobin degradation by protein extracts $(50 \mu \mathrm{g})$ from the gut tissue of female worms (18 $\mathrm{h}$ hydrolysis) tested at different $\mathrm{pHs}$; 1 : haemoglobin (negative control); 2: haemoglobin + protein extract (positive control). Gels were stained with Coomassie Blue. Molecular mass standards are shown on the left side of the gel. and larvae (not shown). It is possible to observe blood inside the intestines of $A$. costaricensis adult worms, thus suggesting that the parasite haemoglobinolytic protease may be involved in the degradation of blood components of the host. These proteases may be responsible for the degradation of haemoglobin and other host proteins during intracellular residence, as already observed for schistosomes (McKerrow et al. 2006). The haemoglobinolytic activity of $A$. costaricensis extracts was effectively inhibited by pepstatin, while APMSF, E-64 and orthophenanthroline had no inhibitory effect (Figs 4, 5). These results indicate the presence of aspartic proteases in larvae and adult worms.

\section{DISCUSSION}

Metalloprotease activity has been already reported in several helminths (Lun et al. 2003, Quiñones et al. 2006, Williamson et al. 2006), including Angiostrongylus cantonensis (Lee et al. 2004, Lai et al. 2005). These enzymes belong to a diverse group of enzymes that utilize coordination to a metal ion (usually zinc) to exert catalysis and have a powerful degrading effect on extracellular matrix components (Rawlings \& Barrett 1995). Because L1 and L3 larvae from A. costaricensis do not possess a bucal stylet (Ishih et al. 1990), one can speculate that the important gelatinolytic activity observed by zymography may assist in parasite penetration into both the mollusk tegument and the intestinal wall. For example, the infective larvae of Strongyloides stercoralis secretes a metalloprotease that is thought to be involved in the invasive process, facilitating the tissue penetration of the host skin (McKerrow et al. 1990, Gomez Gallego et al. 2005). Similarly, the secreted metalloproteases of Ancylostoma caninum appear to trigger the activation of the thirdstage infective larvae, including ecdysis and penetration of host tissues (Hotez et al. 1990, Hawdon et al. 1995, Williamson et al. 2006). Metalloproteases have also been identified in extracts and excretory-secretory samples of A. cantonensis and may be associated with parasite dissemination and/or pathogenesis (Lai et al. 2005).



Fig. 2A: comparison of zymographic and electrophoretic profiles of protein extracts of first (L1) and third (L3) stage larvae of Angiostrongylus costaricensis nematodes. Samples $(2 \mu \mathrm{g})$ were loaded onto $12 \%$ sodium dodecyl sulfate polyacrylamide gel electrophoresis (SDS-PAGE) copolymerized with $0.1 \%$ gelatin. After the electrophoretic separation, the zymograms were incubated for $18 \mathrm{~h}$ at $37^{\circ} \mathrm{C}$ in 0.1 $\mathrm{M}$ Tris containing $1 \mathrm{mM} \mathrm{CaCl}_{2}, \mathrm{pH}$ 7.4. They were stained with Coomassie Brilliant Blue R250. B: SDS-PAGE (12\%) analysis of crude extracts $(2 \mu \mathrm{g})$ stained with silver nitrate. Molecular mass standards are shown on the left side of the gel. 
Several aspartic proteases have also been described in different parasitic nematodes, including hookworms (Williamson et al. 2004), S. stercoralis (Gallego et al. 1998), Haemonchus contortus (Longbottom et al. 1997) and Onchocerca volvulus (Jolodar et al. 2004) and in the free-living nematode Caenorhabditis elegans (Geier et al. 1999). In the hookworms, these proteases play an important role in haemoglobin digestion in the intestine and in tissue degradation during the larvae migration in the mammalian host (Williamson et al. 2003). A recent study showed that the expression level of the aspartic protease gene in $A$. cantonensis varies during the life cycle of the nematode and differs between male and female adult worms (Hwang et al. 2010). Some nematodes express aspartic proteases in eggs and in early stages of development, but a clear function has not yet been ascribed to these enzymes (Yang et al. 2009).

Aspartic proteases are proteolytic enzymes characterized by the presence of two catalytic aspartic acid residues at their active site. These enzymes play a key role in the digestion of haemoglobin by schistosomes (Brinkworth et al. 2001, Koehler et al. 2007), Plasmodium falciparum (Francis et al. 1997, Banerjee et al. 2002), Necator americanus (Brown et al. 1995, 1999) and A. caninum (Williamson et al. 2003). Interestingly, cysteine protease activity was not detected under the experimental conditions tested. This type of protease is the most widely reported class of protease in parasitic nematodes and has been shown to hydrolyze gelatin in addition to other substrates (Yatsuda et al. 2006, Kasny et al. 2007, Liu et al. 2010). Cysteine proteases are associated with several biological processes, such as tissue penetration, feeding and evasion of host immune response (Sajid \& McKerrow 2002).

From a biological point of view, it is interesting to note that L1 extracts showed stronger gelatinolytic activity than L3 extracts. L1 larvae penetrate mollusks through oral (Morera 1973) and/or percutaneous infections (Thiengo 1996, Mendonca et al. 1999) and moult twice inside the intermediate host. We hypothesize that the ability of gelatinases to hydrolyze extracellular matrix components is important for tissue invasion. The stronger gelatinolytic activity of L1 larvae may ensure its successful penetration through the mollusk's surface and muscular layers. However, L3 larvae may also make use of gelatinolytic enzymes to penetrate the vertebrate intestinal wall and reach the circulatory system, as already described for the infective stage of several parasite nematodes (Hotez et al. 1990, Zhan et al. 2002, Lai et al. 2005, Lee \& Yen 2005). L3 become adult worms inside the blood vessels, where these last will live their entire lives. L1 may be eventually found in the systemic circulation, although this results from an alternative migratory route in rodents (Mota \& Lenzi 2005, Fontoura et al. 2007). Therefore, it was not surprising to find that the proteolytic activity against haemoglobin was more pronounced in L3 larvae and adult worms. These developmental stages of the parasite remain in direct contact with blood most of their lifetime.

In summary, in this study we investigated the presence of proteolytic activity in crude protein extracts from different life cycle stages of $A$. costaricensis. Several metalloproteases with gelatinolytic activity were observed in the protein extracts from L1 and L3 larvae, but not in adult
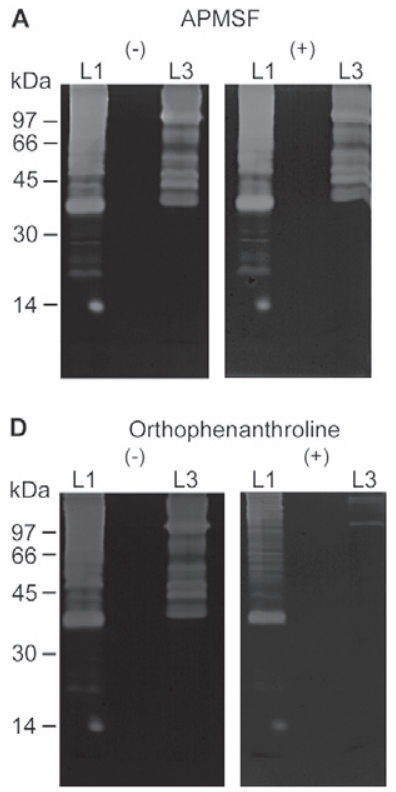



Fig. 3: effect of protease inhibitors on the zymographic profiles of the protein extracts of first (L1) and third (L3) larvae of Angiostrongylus costaricensis nematodes. L1 or L3 samples were loaded onto $12 \%$ sodium dodecyl sulfate polyacrylamide gel electrophoresis copolymerized with $0.1 \%$ gelatin. After the electrophoretic separation, the zymograms were incubated for $18 \mathrm{~h}$ at $37^{\circ} \mathrm{C}$ in $0.1 \mathrm{M}$ Tris containing $1 \mathrm{mM} \mathrm{CaCl}, \mathrm{pH} 7.4$. The proteolytic activity was assayed in the absence (-) or presence (+) of each one of the protease inhibitors [A: $100 \mu \mathrm{M} 4-($ amidinophenyl) methanesulphonyl fluoride (APMSF); B: $10 \mu \mathrm{M}$ L-trans-epoxysuccinyl-L-leucylamido-(4-guanidino)-butane (E-64); C: $1 \mu \mathrm{M}$ pepstatin-A; D: $10 \mathrm{mM}$ orthophenanthroline; E: 10 mM ethylenediaminetetraacetic acid (EDTA); F: 10 mM ethyleneglycol bis(2-aminoethyl ether)-N,N,N',N' tetraacetic acid (EGTA)]. Zymograms were stained with Coomassie Brilliant Blue R250. Molecular mass standards are shown on the left side of the gel. 
A



B

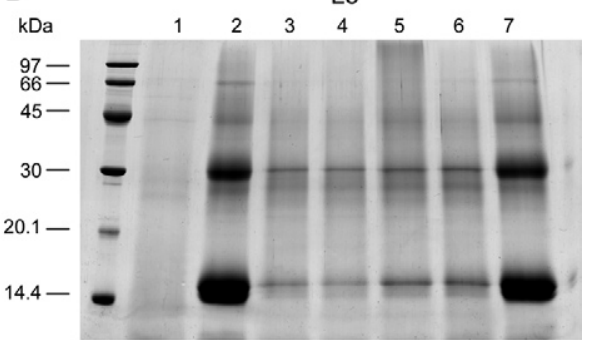

Fig. 4: human haemoglobin hydrolyzed by protein extracts of first-stage larvae (L1) (A) or third-stage larvae (L3) (B) of Angiostrongylus costaricensis nematodes. Haemoglobin solubilised in $0.1 \mathrm{M}$ sodium citrate buffer $\mathrm{pH} 3.0$ was incubated with $50 \mu \mathrm{g}$ of larval extracts for $18 \mathrm{~h}$ at $37^{\circ} \mathrm{C}$. To assay for inhibition, the haemoglobin substrate was incubated with the larval extract in the presence of different protease inhibitors. Lane 1: crude larval extract; 2: haemoglobin (negative control); 3: haemoglobin + larval extract (positive control); 4: haemoglobin + larval extract + $10 \mu \mathrm{M} \mathrm{L-trans-ep-}$ oxysuccinyl-L-leucylamido-(4-guanidino)-butane; 5: haemoglobin + larval extract + $10 \mathrm{mM}$ orthophenanthroline; 6: haemoglobin + larval extract $+100 \mu \mathrm{M} 4$-(amidinophenyl) methanesulphonyl fluoride; 7: haemoglobin + larval extract $+1 \mu \mathrm{M}$ pepstatin. Sodium dodecyl sulfate polyacrylamide gel electrophoresis (15\%) were stained with Coomassie Brilliant Blue R250. Molecular mass standards are shown on the left side of the gel.

A

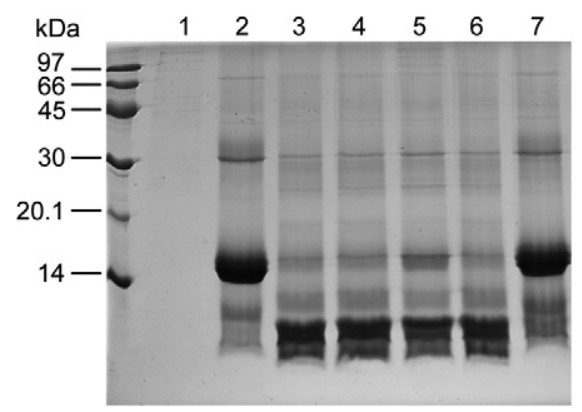

B

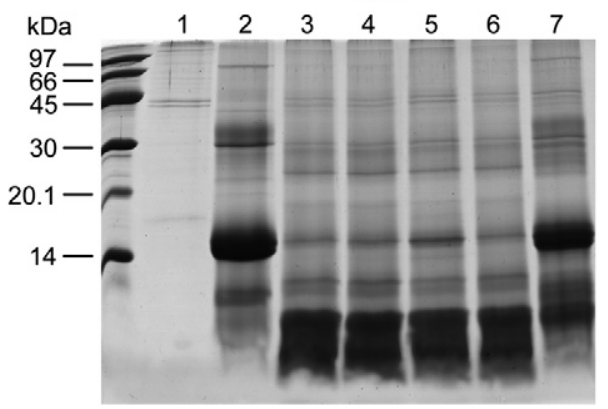

Fig. 5: human haemoglobin hydrolyzed by protein extracts of adult female (A) or male (B) Angiostrongylus costaricensis nematodes. Haemoglobin solubilised in $0.1 \mathrm{M}$ sodium citrate buffer $\mathrm{pH} 3.0$ was incubated with $50 \mu \mathrm{g}$ of worm extracts for $5 \mathrm{~h}$ at $37^{\circ} \mathrm{C}$. To assay for inhibition, the haemoglobin substrate was incubated with the worm extract in the presence of different protease inhibitors. Lane 1: crude worm extract; 2: haemoglobin (negative control); 3: haemoglobin + worm extract (positive control); 4: haemoglobin + worm extract + $10 \mu \mathrm{M} \mathrm{L-trans-epoxysuccinyl-}$ L-leucylamido-(4-guanidino)-butane; 5: haemoglobin + worm extract $+10 \mathrm{mM}$ orthophenanthroline; 6 : haemoglobin + worm extract $+100 \mu \mathrm{M}$ 4-(amidinophenyl) methanesulphonyl fluoride; 7: haemoglobin + worm extract $+1 \mu \mathrm{M}$ pepstatin. Sodium dodecyl sulfate polyacrylamide gel electrophoresis (15\%) were stained with Coomassie Brilliant Blue R250. Molecular mass standards are shown on the left side of the gel.

worm extracts. They showed optimal activity at neutral to alkaline $\mathrm{pH}$. At low $\mathrm{pH}$, haemoglobinolytic enzymes characterized as aspartic proteases were detected both in larvae and adult worms. The results suggest that these haemoglobin-degrading proteases should ideally exert their activity under an acid environment, such as the intestine. Although the biological function of the proteases from $A$. costaricensis remains unknown, they represent an attractive target for the development of diagnostic tests and vaccines for the control of abdominal angiostrongyliasis.

\section{ACKNOWLEDGEMENTS}

To Heloisa MN Diniz, for processing the figures.

\section{REFERENCES}

Abrahams-Sandi E, Mesén-Ramirez P, Suarez-Chacon D, FernándezQuesada K 2011. An indirect immunofluorescence antibody test employing whole eggs as the antigen for the diagnosis of abdominal angiostrongyliasis. Mem Inst Oswaldo Cruz 106: 390-393.

Agostini AA, Marcolan AM, Lisot JM, Lisot JU 1984. Angiostrongilíase abdominal. Estudo anátomo-patológico de quatro casos obser- vados no Rio Grande do Sul, Brasil. Mem Inst Oswaldo Cruz 79: 443-445.

Agostini AA, Peixoto A, Caleffi AL, Dexhaimer A, Camargo RR 1983. Angiostrongilíase abdominal: três casos observados no Rio Grande do Sul. Rev Assoc Med Rio Grande do Sul 27: 200-203.

Ayala MA 1987. Angiostrongiloidíase abdominal. Seis casos observados no Paraná e em Santa Catarina, Brasil. Mem Inst Oswaldo Cruz 82: 29-36.

Banerjee R, Liu J, Beatty W, Pelosof L, Klemba M, Goldberg DE 2002. Four plasmepsins are active in the Plasmodium falciparum food vacuole, including a protease with an active-site histidine. Proc Natl Acad Sci USA 99: 990-995.

Barcante JM, Barcante TA, Dias SR, Vieira LQ, Lima WS, NegraoCorrea D 2003. A method to obtain axenic Angiostrongylus vasorum first-stage larvae from dog feces. Parasitol Res 89: 89-93.

Ben R, Rodrigues R, Agostini AA, Graeff-Teixeira C 2010. Use of heterologous antigens for the immunodiagnosis of abdominal angiostrongyliasis by an enzyme-linked immunosorbent assay. Mem Inst Oswaldo Cruz 105: 914-917.

Bender AL, Maurer RL, da Silva MC, Ben R, Terraciano PB, da Silva AC, Graeff-Teixeira C 2003. Eggs and reproductive or- 
gans of female Angiostrongylus costaricensis are more intensely recognized by human sera from acute phase in abdominal angiostrongyliasis. Rev Soc Bras Med Trop 36: 449-454.

Bohrer Mentz M, Dallegrave E, Agostini A, Graeff-Teixeira C 2007. Phenantroline, lovastatin and mebendazole do not inhibit oviposition in the murine experimental infection with Angiostrongylus costaricensis. Parasitol Res 100: 379-382.

Brinkworth RI, Prociv P, Loukas A, Brindley PJ 2001. Hemoglobindegrading, aspartic proteases of blood-feeding parasites: substrate specificity revealed by homology models. J Biol Chem 276: 38844-38851.

Brown A, Burleigh JM, Billett EE, Pritchard DI 1995. An initial characterization of the proteolytic enzymes secreted by the adult stage of the human hookworm Necator americanus. Parasitology 110: 555-563.

Brown A, Girod N, Billett EE, Pritchard DI 1999. Necator americanus (human hookworm) aspartyl proteinases and digestion of skin macromolecules during skin penetration. Am J Trop Med Hyg 60: 840-847.

Chung YB, Kong Y, Joo IJ, Cho SY, Kang SY 1995. Excystment of Paragonimus westermani metacercariae by endogenous cysteine protease. J Parasitol 81: 137-142.

Dalton J 2003. Helminth vaccines: from mining genomic information for vaccine targets to systems used for protein expression. Int $J$ Parasitol 33: 621-640.

da Silva AC, Graeff-Teixeira C, Zaha A 2003. Diagnosis of abdominal angiostrongyliasis by PCR from sera of patients. Rev Inst Med Trop Sao Paulo 45: 295-297.

d'Avila-Levy CM, Melo AC, Vermelho AB, Branquinha MH 2001. Differential expression of proteolytic enzymes in endosymbiontharboring Crithidia species. FEMS Microbiol Lett 202: 73-77.

Dzik JM 2006. Molecules released by helminth parasites involved in host colonization. Acta Biochim Pol 53: 33-64.

Fante CA, Dieterish S, Rodriguez R 2008. Betamethasone and aqueous extract of Arctium lappa for treating angiostrongyliasis. Rev Soc Bras Med Trop 41: 654-657.

Fontoura GD, Maurer RL, Oliveira CM, Graeff-Teixeira C 2007. Abdominal angiostrongyliasis in rodent experimental infection: evidence for systemic circulation of first stage larvae. Parasitol Int 56: 227-229.

Francis SE, Sullivan DJ Jr, Goldberg DE 1997. Hemoglobin metabolism in the malaria parasite Plasmodium falciparum. Annu Rev Microbiol 51: 97-123.

Gallego SG, Slade RW, Brindley PJ 1998. A cDNA encoding a pepsinogen-like, aspartic protease from the human roundworm parasite Strongyloides stercoralis. Acta Trop 71: 17-26.

Geier G, Banaj HJ, Heid H, Bini L, Pallini V, Zwilling R 1999. Aspartyl proteases in Caenorhabditis elegans. Isolation, identification and characterization by a combined use of affinity chromatography, two-dimensional gel electrophoresis, microsequencing and databank analysis. Eur J Biochem 264: 872-879.

Geiger SM, Abrahams-Sandi E, Soboslay PT, Hoffmann WH, Pfaff AW, Graeff-Teixeira C, Schulz-Key H 2001. Cellular immune responses and cytokine production in BALB/c and $\mathrm{C} 57 \mathrm{BL} / 6$ mice during the acute phase of Angiostrongylus costaricensis infection. Acta Trop 80: 59-68.

Gomez Gallego S, Loukas A, Slade RW, Neva FA, Varatharajalu R, Nutman TB, Brindley PJ 2005. Identification of an astacinlike metallo-proteinase transcript from the infective larvae of Strongyloides stercoralis. Parasitol Int 54: 123-133.

Graeff-Teixeira C, Agostini AA, Camillo-Coura L, Ferreira-da-Cruz MF 1997. Seroepidemiology of abdominal angiostrongyliasis: the standardization of an immunoenzymatic assay and prevalence of antibodies in two localities in southern Brazil. Trop Med Int Health 2: 254-260.

Graeff-Teixeira C, Camillo-Coura L, Lenzi HL 1991. Clinical and epidemiological aspects of abdominal angiostrongyliasis in southern Brazil. Rev Inst Med Trop Sao Paulo 33: 373-378.

Graeff-Teixeira C, Geiger S, Walderich B, Hoffmann W, Abrahams E, Schulz-Key H 1999. Isolation of Angiostrongylus costaricensis first-stage larvae from rodent feces on a Percoll gradient. J Parasitol 85: 1170-1171.

Graeff-Teixeira C, Goulart AH, Brum C de O, Laitano AC, Sievers-Tostes C, Zanini GM, Bered PL, Morassutti A, Geiger S, Abrahms-Sandi E, Oliveira FT, Maurer RL, Aguiar LF, Garrido CT, da Silva AC, Rodriguez R, Schulz-Key H, Agostini AA 2005. Longitudinal clinical and serological survey of abdominal angiostrongyliasis in Guaporé, southern Brazil, from 1995 to 1999. Rev Soc Bras Med Trop 38: 310-315.

Hawdon JM, Jones BF, Perregaux MA, Hotez PJ 1995. Ancylostoma caninum: metalloprotease release coincides with activation of infective larvae in vitro. Exp Parasitol 80: 205-211.

Heussen C, Dowdle EB 1980. Electrophoretic analysis of plasminogen activators in polyacrylamide gels containing sodium dodecyl sulfate and copolymerized substrates. Anal Biochem 102: 196-202.

Hong X, Bouvier J, Wong MM, Yamagata GY, McKerrow JH 1993. Brugia pahangi: identification and characterization of an aminopeptidase associated with larval molting. Exp Parasitol 76: 127-133.

Hotez P, Haggerty J, Hawdon J, Milstone L, Gamble HR, Schad G, Richards F 1990. Metalloproteases of infective Ancylostoma hookworm larvae and their possible functions in tissue invasion and ecdysis. Infect Immun 58: 3883-3892.

Hwang KP, Chang SH, Wang LC 2010. Alterations in the expression level of a putative aspartic protease in the development of $\mathrm{An}$ giostrongylus cantonensis. Acta Trop 113: 289-294.

Incani RN, Caleiras E, Martin M, Gonzalez C 2007. Human infection by Angiostrongylus costaricensis in Venezuela: first report of a confirmed case. Rev Inst Med Trop Sao Paulo 49: 197-200.

Ishih A, Rodriguez BO, Sano M 1990. Scanning electron microscopic observations of first and third-stage larvae and adults of $A n$ giostrongylus costaricensis. Southeast Asian J Trop Med Public Health 21: 568-573.

Jolodar A, Fischer P, Buttner DW, Miller DJ, Schmetz C, Brattig NW 2004. Onchocerca volvulus: expression and immunolocalization of a nematode cathepsin D-like lysosomal aspartic protease. Exp Parasitol 107: 145-156.

Kasny M, Mikes L, Dalton JP, Mountford AP, Horak P 2007. Comparison of cysteine peptidase activities in Trichobilharzia regenti and Schistosoma mansoni cercariae. Parasitology 134: 1599-1609.

Koehler JW, Morales ME, Shelby BD, Brindley PJ 2007. Aspartic protease activities of schistosomes cleave mammalian hemoglobins in a host-specific manner. Mem Inst Oswaldo Cruz 102: 83-85.

Laemmli UK 1970. Cleavage of structural proteins during the assembly of the head of bacteriophage T4. Nature 227: 680-685.

Lai SC, Jiang ST, Chen KM, Lee HH 2005. Matrix metalloproteinases activity demonstrated in the infective stage of the nematodes, $A n$ giostrongylus cantonensis. Parasitol Res 97: 466-471.

Lee HH, Chou HL, Chen KM, Lai SC 2004. Association of matrix metalloproteinase-9 in eosinophilic meningitis of BALB/c mice caused by Angiostrongylus cantonensis. Parasitol Res 94: 321-328.

Lee JD, Yen CM 2005. Protease secreted by the infective larvae of $A n$ giostrongylus cantonensis and its role in the penetration of mouse intestine. Am J Trop Med Hyg 72: 831-836. 
Lim MD, Craik CS 2009. Using specificity to strategically target proteases. Bioorg Med Chem 17: 1094-1100.

Liu YH, Han YP, Li ZY, Wei J, He HJ, Xu CZ, Zheng HQ, Zhan XM, Wu ZD, Lv ZY 2010. Molecular cloning and characterization of cystatin, a cysteine protease inhibitor, from Angiostrongylus cantonensis. Parasitol Res 107: 915-922.

Longbottom D, Redmond DL, Russell M, Liddell S, Smith WD, Knox DP 1997. Molecular cloning and characterisation of a putative aspartate proteinase associated with a gut membrane protein complex from adult Haemonchus contortus. Mol Biochem Parasitol 88: 63-72.

Lopez-Otin C, Bond JS 2008. Proteases: multifunctional enzymes in life and disease. $J$ Biol Chem 283: 30433-30437.

Lun HM, Mak CH, Ko RC 2003. Characterization and cloning of metallo-proteinase in the excretory/secretory products of the infective-stage larva of Trichinella spiralis. Parasitol Res 90: 27-37.

McKerrow JH 1989. Parasite proteases. Exp Parasitol 68: 111-115.

McKerrow JH, Brindley P, Brown M, Gam AA, Staunton C, Neva FA 1990. Strongyloides stercoralis: identification of a protease that facilitates penetration of skin by the infective larvae. Exp Parasitol 70: 134-143.

McKerrow JH, Caffrey C, Kelly B, Loke P, Sajid M 2006. Proteases in parasitic diseases. Annu Rev Pathol 1: 497-536.

Mendonca CLGF, Carvalho OS, Mota EM, Pelajo-Machado M, Caputo LFG, Lenzi HL 1999. Penetration sites and migratory routes of $\mathrm{An}$ giostrongylus costaricensis in the experimental intermediate host (Sarasinula marginata). Mem Inst Oswaldo Cruz 94: 549-556.

Mentz MB, Graeff-Teixeira C 2003. Drug trials for treatment of human angiostrongyliasis. Rev Inst Med Trop Sao Paulo 45: 179-184.

Mesen-Ramirez P, Abrahams-Sandi E, Fernandez-Quesada K, Morera P 2008. Angiostrongylus costaricensis egg antigen for the immunodiagnosis of abdominal angiostrongyliasis. $J$ Helminthol 82: 251-254.

Morera P 1973. Life history and redescription of Angiostrongylus costaricensis Morera and Céspedes, 1971. Am J Trop Med Hyg 22: 613-621.

Morera P, Bontempo I 1985. Acción de algunos antihelminticos sobre Angiostrongylus costaricensis. Rev Med Hosp Nac Niños (Costa Rica) 20: 165-174

Morera P, Cespedes R 1970. Angiostrongylus costaricensis n. sp. (Nematoda: Metastrongyloidea), a new lungworm occurring in man in Costa Rica. Rev Biol Trop 18: 173-185.

Morera P, Cespedes R 1971. Angiostrongilosis abdominal. Uma nueva parasitosis humana. Acta Med Costarric 14: 173-189.

Mota EM, Lenzi HL 2005. Angiostrongylus costaricensis: complete redescription of the migratory pathways based on experimental Sigmodon hispidus infection. Mem Inst Oswaldo Cruz 100: 407-420.

Palominos PE, Gasnier R, Rodriguez R, Agostini AA, Graeff-Teixeira C 2008. Individual serological follow-up of patients with suspected or confirmed abdominal angiostrongyliasis. Mem Inst Oswaldo Cruz 103: 93-97.

Quiñones AM, Torres RJ, Rubin MR 2006. Biochemical detection, pharmacological inhibition and phylogenetic analysis of Caenorhabditis elegans metalloproteases. BIOS 77: 113-126.

Rawlings ND, Barrett AJ 1995. Evolutionary families of metallopeptidases. Methods Enzymol 248: 183-228.

Rawlings ND, Barrett AJ, Bateman A 2012. MEROPS: the database of proteolytic enzymes, their substrates and inhibitors. Nucleic Acids Res 40: D343-350.
Rebello KM, Barros JS, Mota EM, Carvalho PC, Perales J, Lenzi HL, Neves-Ferreira AG 2011. Comprehensive proteomic profiling of adult Angiostrongylus costaricensis, a human parasitic nematode. J Proteomics 74: 1545-1559.

Rhoads ML, Fetterer RH, Urban JF Jr 1998. Effect of protease classspecific inhibitors on in vitro development of the third to fourthstage larvae of Ascaris suum. J Parasitol 84: 686-690.

Rodriguez R, Porto SM, Dos Santos Ferrari R, Marcolan AM, da Silva AC, Graeff-Teixeira C, Fornari F 2011. Outcomes in mice with abdominal angiostrongyliasis treated with enoxaparin. Parasitol Res 109: 787-792.

Sajid M, McKerrow JH 2002. Cysteine proteases of parasitic organisms. Mol Biochem Parasitol 120: 1-21.

Santos LO, Marinho FA, Altoe EF, Vitorio BS, Alves CR, Britto C, Motta MC, Branquinha MH, Santos AL, d'Avila-Levy CM 2009. HIV aspartyl peptidase inhibitors interfere with cellular proliferation, ultrastructure and macrophage infection of Leishmania amazonensis. PLoS ONE 4: e4918.

Terada M, Kino H, Akyol CV, Sano M 1993. Effects of mebendazole on Angiostrongylus costaricensis in mice, with special reference to the timing of treatment. Parasitol Res 79: 441-443.

Thiengo SC 1996. Mode of infection of Sarasinula marginata (Mollusca) with larvae of Angiostrongylus costaricensis (Nematoda). Mem Inst Oswaldo Cruz 91: 277-278.

Tort J, Brindley PJ, Knox D, Wolfe KH, Dalton JP 1999. Proteinases and associated genes of parasitic helminths. Adv Parasitol 43: 161-266.

Tungtrongchitr A, Ishih A, Terada M, Radomyos P 1993. Effects of sensitization on efficacy of mebendazole in mice infected with adult Angiostrongylus costaricensis. Trop Med Parasitol 44: 322-326.

Wallace GRL 1969. Techniques for recovering and identifying larvae of Angiostrongylus cantonensis from mollusks. Malacologia 7: 427-438.

Wilkesman J, Kurz L 2009. Protease analysis by zymography: a review on techniques and patents. Rec Pat Biotechnol 3: 175-184.

Williamson AL, Brindley PJ, Knox DP, Hotez PJ, Loukas A 2003. Digestive proteases of blood-feeding nematodes. Trends Parasitol 19: 417-423.

Williamson AL, Lecchi P, Turk BE, Choe Y, Hotez PJ, McKerrow JH, Cantley LC, Sajid M, Craik CS, Loukas A 2004. A multi-enzyme cascade of hemoglobin proteolysis in the intestine of blood-feeding hookworms. $J$ Biol Chem 279: 35950-35957.

Williamson AL, Lustigman S, Oksov Y, Deumic V, Plieskatt J, Mendez S, Zhan B, Bottazzi ME, Hotez PJ, Loukas A 2006. Ancylostoma caninum MTP-1, an astacin-like metalloprotease secreted by infective hookworm larvae, is involved in tissue migration. Infect Immun 74: 961-967.

Xu YZ, Dresden MH 1986. Leucine aminopeptidase and hatching of Schistosoma mansoni eggs. J Parasitol 72: 507-511.

Yang Y, Wei H, Qin W, Zheng J 2009. Expression and characterization of aspartic protease gene in eggs and larvae stage of Ancylostoma caninum. Parasitol Res 104: 1327-1333.

Yatsuda AP, Bakker N, Krijgsveld J, Knox DP, Heck AJ, de Vries E 2006. Identification of secreted cysteine proteases from the parasitic nematode Haemonchus contortus detected by biotinylated inhibitors. Infect Immun 74: 1989-1993.

Zhan B, Hotez PJ, Wang Y, Hawdon JM 2002. A developmentally regulated metalloprotease secreted by host-stimulated Ancylostoma caninum third-stage infective larvae is a member of the astacin family of proteases. Mol Biochem Parasitol 120: 291-296. 